\section{Fast forward for gene therapy}

Last month's approval by the Recombinant DNA Advisory Committee (RAC) of the National Institutes of Health (NIH) of three independent proposals to begin limited trials for the severe hereditary lung disease, cystic fibrosis (CF), heralds a new era in gene-therapy research for common hereditary diseases.

Until now, gene therapy has focused largely on expensive ex vivo approaches for rare diseases, including certain forms of cancer and immunodeficiency, although the RAC last year also approved ambitious proposals for brain and lung cancer. By contrast, the $\mathrm{CF}$ proposals call for the direct administration in vivo of the normal $\mathrm{CF}$ gene encapsulated within an adenovirus vector. Despite earlier concerns about the safety of such viruses and the efficacy with which they can be prevented from replicating, the RAC passed the three proposals unanimously. Many experts believe that such direct administration is necessary to realize the true potential of gene therapy in a clinical setting.

In the United States, at least 15 clinical gene-therapy trials are in progress, so far with mixed results. Efforts to treat rare genetic disorders such as adenine deaminase (ADA) deficiency in two children and familial hypercholesterolaemia $(\mathrm{FH})$ in an adult woman are proving effective. Indeed, James Wilson of the University of Michigan, whose team is treating the female $\mathrm{FH}$ patient with the low-density lipoprotein receptor gene, was recently granted permission by RAC to extend the study to four new patients. By contrast, studies using transformed tumour infiltrating lymphocytes have come under fire (see Nature 360, 399; 1992) and many other trials have not yet yielded conclusive results. Research questions remain about the purification of viruses in large quantities and the targeting of specific populations of cells.

The next twelve months may see European researchers gaining ground. Two prominent European investigators, Dinko Valerio in the Netherlands and Claudio Bordignon in Italy, are already attempting to target stem cells to prolong the effectiveness of the treatment for ADA deficiency. In Germany, a proposal by Roland Mertelsmann to transfect the cytokine interleukin 2 into fibroblasts before using them as a vaccine for cancer patients was recently approved by the state of BadenWürtenberg (see Nature 360, 702; 1992).

In Britain, however, a proposal by Valerio's collaborators to begin trials for ADA deficiency, as well as a separate strategy for $\mathrm{CF}$ therapy from investigators in London, have suffered because the government has not yet set up a formal expert review board. Similar concerns among other European investigators regarding the paucity of approved gene-therapy trials has prompted some to approach the RAC about the possibility of using it to examine European-based proposals.

With anxieties about the safety issues and effectiveness of gene therapy decreasing, 1993 could see a spate of new proposals as investigators turn to new diseases and alternative strategies to deliver healthy genes. Many other proposals are likely to be of the 'gene marketing' variety, in which researchers tag populations of cells such as bone marrow cells with a recombinant marker gene before transplanting them back into the host.

Kevin Davies

\section{Recession grips industrial R\&D}

This year seems likely to be another gloomy 12 months for industrial research and development (R\&D) as the global recession continues to depress spending and force cutbacks in research. One of the few bright spots is the pharmaceutical industry, which is weathering the recession with continued heavy investment in drug development.

Last year, even Japan, which maintained buoyant growth into the $1990 \mathrm{~s}$, found it could not escape the tide of recession. Major players in Japan's industrial research, such as the electronics and automobile industries, have been forced to freeze $R \& D$ budgets as their profits fell to all-time lows (see Nature 356, $93 ; 1992)$. The end of 1992 saw International Business Machines (IBM) announce a cut of $\$ 1$ billion in its planned outlay on R\&D worldwide in 1993, the latest in a string of bad economic news that included last summer's announcement by British Petroleum that it will shed nearly half of its research staff in Britain and the United States (see Nature 358, 528; 1992).

Prospects for the coming year look even grimmer. An end-of-year survey by the Washington-based Industrial Research Institute, an organization representing 260 prominent industrial companies, predicts that the recession will hit $R \& D$ spending in the United States even harder in 1993. More than a quarter ( 28 per cent) of the 141 companies replying to the survey say that they plan to cut their R\&D budgets this year and even more ( 36 per cent) will spend less on equipment and R\&D facilities. In Japan, the recession has prompted some bizarre economy measures, including switching off the heating during lunch breaks and eliminating business cards for researchers (see Nature 360, 98; 1992).
Despite a supplementary budget of more than $¥ 10,000$ billion (US\$80 billion) introduced by the Japanese government a few months ago to boost the economy, the recession in Japan is expected to continue well into this year, and many observers predict that companies will be forced to slash their R\&D budgets during the 1993 fiscal year, which begins on 1 April.

The recession is also affecting Japanese government research spending. Nevertheless, industry, including some non-Japanese companies, is turning to Japan's Ministry of International Trade and Industry (MITI) for support of long-term precompetitive research.

The situation is particularly severe in Europe because of the costs of reunifying Germany. In western Germany, 1,500 research positions will be shed in national research institutes and Germany has cut its funding to large-scale European projects, such as the European Space Agency and CERN (the European Laboratory for Particle Physics) (see Nature 360, 701; 1992). The development of a strong research base in Spain through increased government spending has also been delayed by the recession (see Nature 360, 502; 1992). And the leading government organization for applied research in the Netherlands, the TNO, has been told to find more money from industry because of cutbacks in government support (see Nature 360, 402; 1992).

The only bright spot in all the gloom is

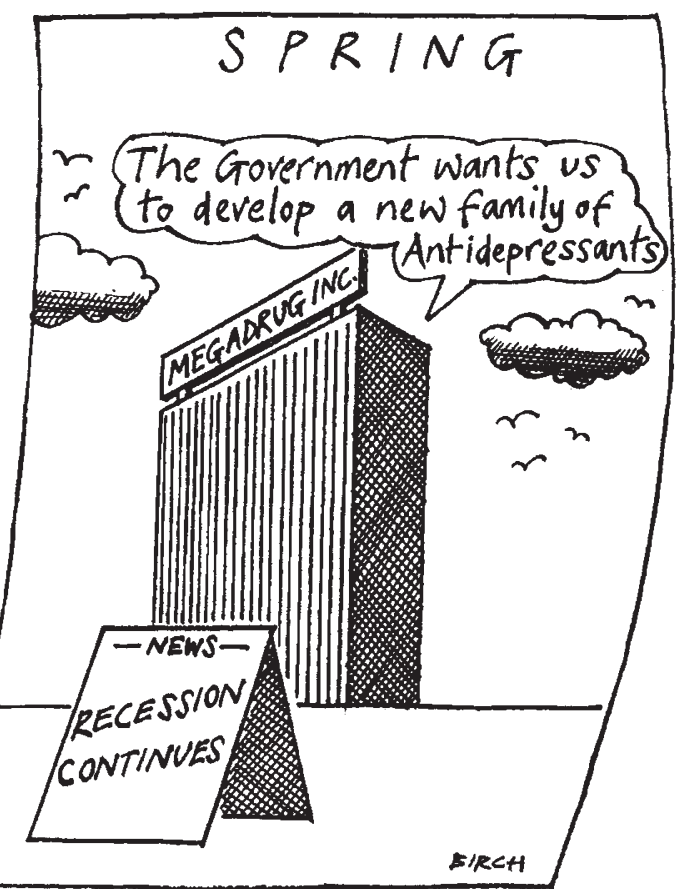

the drug industry. As one of the directors of Japan's Takeda Pharmaceutical company puts it, "people have to continue buying drugs even in a recession". Glaxo, the British-based pharmaceutical group and one of the largest companies in the world, plans to boost its R\&D spending from $£ 600$ million 